\title{
Increased betulinic acid induced cytotoxicity and radiosensitivity in glioma cells under hypoxic conditions
}

Matthias Bache ${ }^{1 *}$, Martin P Zschornak ${ }^{1 \dagger}$, Sarina Passin ${ }^{1 \dagger}$, Jacqueline Keßler $^{1}$, Henri Wichmann ${ }^{1}$, Matthias Kappler ${ }^{1,2}$, Reinhard Paschke ${ }^{3}$, Goran N Kaluđerović ${ }^{3}$, Harish Kommera ${ }^{3}$, Helge Taubert ${ }^{2,4}$ and Dirk Vordermark ${ }^{1}$

\begin{abstract}
Background: Betulinic acid (BA) is a novel antineoplastic agent under evaluation for tumor therapy. Because of the selective cytotoxic effects of BA in tumor cells (including gliomas), the combination of this agent with conservative therapies (such as radiotherapy and chemotherapy) may be useful. Previously, the combination of BA with irradiation under hypoxic conditions had never been studied.

Methods: In this study, the effects of 3 to $30 \mu \mathrm{M}$ BA on cytotoxicity, migration, the protein expression of PARP, survivin and HIF-1 $\alpha$, as well as radiosensitivity under normoxic and hypoxic conditions were analyzed in the human malignant glioma cell lines U251MG and U343MG. Cytotoxicity and radiosensitivity were analyzed with clonogenic survival assays, migration was analyzed with Boyden chamber assays (or scratch assays) and protein expression was examined with Western blot analyses.

Results: Under normoxic conditions, a half maximal inhibitory concentration $\left(\mathrm{IC}_{50}\right)$ of $23 \mu \mathrm{M}$ was observed in U251MG cells and $24 \mu \mathrm{M}$ was observed in U343MG cells. Under hypoxic conditions, $10 \mu \mathrm{M}$ or $15 \mu \mathrm{M}$ of BA showed a significantly increased cytotoxicity in U251MG cells ( $p=0.004$ and $p=0.01$, respectively) and U343MG cells ( $p<0.05$ and $p=0.01$, respectively). The combination of BA with radiotherapy resulted in an additive effect in the U343MG cell line under normoxic and hypoxic conditions. Weak radiation enhancement was observed in U251MG cell line after treatment with BA under normoxic conditions. Furthermore, under hypoxic conditions, the incubation with BA resulted in increased radiation enhancement. The enhancement factor, at an irradiation dose of 15 Gy after treatment with 10 or $15 \mu \mathrm{M} \mathrm{BA}$, was $2.20(p=0.02)$ and $4.50(p=0.03)$, respectively. Incubation with BA led to decreased cell migration, cleavage of PARP and decreased expression levels of survivin in both cell lines. Additionally, BA treatment resulted in a reduction of HIF-1 $\alpha$ protein under hypoxic conditions.
\end{abstract}

Conclusion: Our results suggest that BA is capable of improving the effects of tumor therapy in human malignant glioma cells, particularly under hypoxic conditions. Further investigations are necessary to characterize its potential as a radiosensitizer.

Keywords: betulinc acid, glioma cells, hypoxia, irradiation

\footnotetext{
* Correspondence: matthias.bache@medizin.uni-halle.de

† Contributed equally

'Department of Radiotherapy, Martin-Luther-University Halle-Wittenberg,

Dryanderstr. 4, 06110 Halle, Germany

Full list of author information is available at the end of the article
} 


\section{Background}

Glioblastoma is the most frequent primary brain tumor and is characterized by a poor patient prognosis. Although radiotherapy is widely used for the treatment of patients with glioblastoma, the intrinsic radioresistance of these tumors remains a critical problem in the management of such patients [1]. Betulinic acid (BA) represents a new therapeutic agent with possible use in the treatment of glioblastoma. BA, a pentacyclic triterpene, can be synthesized by the oxidation of betulin, a substance found in the bark of birch trees. Additionally, it can also be directly isolated from certain plants. BA has several therapeutic uses. It has been used to treat inflammation, malaria, HIV and as an antimicrobial drug. In addition, BA seems capable of improving tumor therapies. For example, BA is cytotoxic in different tumor cell lines, including neuroectodermal tumors, melanoma, colon, lung and ovarian carcinoma, head and neck cancers and sarcoma [2-4]. Experiments in animals revealed that $\mathrm{BA}$ also has an antitumor effect in vivo [5-7]. Interestingly, the cytotoxicity of BA in tumor cells occurs regardless of whether there is a genetic defect in p53 [6,8]. Remarkably, untransformed, normal cells (in comparison to tumor cells) seem to tolerate relatively high concentrations of BA. Thus, BA is not toxic up to a concentration of $200-400 \mathrm{mg} / \mathrm{kg}$ of body weight in rats or $500 \mathrm{mg} / \mathrm{kg}$ of body weight in mice $[5,9]$.

Different studies have shown that BA induces apoptosis [8,10-13]. In addition, BA's effects on cell migration, cell invasion and angiogenesis inhibition have been demonstrated [14-16]. Furthermore, reactive oxygen radicals generated by $B A$ have been shown to cause significant DNA damage [17-19]. The finding that BA can both induce the formation of reactive oxygen radicals and induce apoptosis could make it attractive for the treatment of hypoxic tumors. The role of hypoxia in developing a more aggressive tumor phenotype in glioma has been previously discussed [20-22]. Because of the selective and wide-range cytotoxic effects of BA in tumor cells, the combination of BA with conservative therapies (such as radiotherapy and chemotherapy) seemed like a promising therapeutic strategy to investigate. Indeed, investigations have shown that BA enhances the cytotoxic effects of vincristine in the B16F10 melanoma cell line [7]. Additionally, sublines of SNU-C5 colon cancer cells that are resistant to chemotherapy showed a significantly increased cytotoxicity when either 5-fluorouracil, irinotecan, or oxaliplatin were combined with BA treatment [23]. Two studies examining the combination of BA and radiotherapy (in melanoma or head and neck cancer cell lines) detected an additive effect on clonogenic survival $[24,25]$. However, there have been no studies examining BA treatment in combination with irradiation under hypoxic conditions. In this study, we analyzed the effects of BA on the cytotoxicity, migration, protein expression of PARP, survivin and HIF- $1 \alpha$ and radiosensitivity under normoxic and hypoxic conditions in the radioresistant glioma U251MG and U343MG cell lines.

\section{Methods}

\section{Cell culture conditions, treatments with BA and} irradiation

The human malignant glioma cell lines U251MG and U343MG (American Type Culture Collection) were grown in RPMI 1640 medium (Lonza, Walkersville, MD, USA) containing $10 \%$ fetal bovine serum (PAA, Cölbe, Germany), 1\% sodium pyruvate (Invitrogen, Karlsruhe, Germany), $185 \mathrm{U} / \mathrm{ml}$ penicillin (Invitrogen) and $185 \mu \mathrm{g} /$ $\mathrm{ml}$ streptomycin (Invitrogen) at $37^{\circ} \mathrm{C}$ in a humidified atmosphere containing $3 \% \mathrm{CO}_{2}$. Hypoxia $\left(<1 \% \mathrm{O}_{2}\right)$ was achieved using a gas generator system as previously described [26]. All experiments were performed with cells in their logarithmic growth phase. BA (Biosolution $\mathrm{GmbH}$, Halle, Germany) was dissolved in dimethyl sulfoxide (DMSO) to achieve a $20 \mathrm{mM}$ stock solution. Cells $\left(3 \times 10^{5}\right)$ were seeded in $25 \mathrm{~cm}^{2}$ flasks 24 h before treatment with 3 to $30 \mu \mathrm{M}$ BA. Cells were treated with BA or DMSO for $24 \mathrm{~h}$ at $37^{\circ} \mathrm{C}$ under normoxic or hypoxic conditions. Additionally, cells were irradiated in tissue culture flasks (Greiner, Frickenhausen, Germany) with 2, 6 or 15 Gy 24 h after incubation with BA. Irradiation was accomplished with $6 \mathrm{MV}$ photons and adequate bolus material on a SIEMENS ONCOR (Erlangen, Germany) linear accelerator at a dose rate of $2 \mathrm{~Gy} / \mathrm{min}$. At 1,24 or $48 \mathrm{~h}$ after irradiation, cells were harvested for clonogenic assays, protein extraction and migration assays.

\section{Clonogenic survival assays and radiosensitivity}

The cytotoxicity of BA was evaluated using the clonogenic survival assay. The cells were trypsinized $1 \mathrm{~h}$ after irradiation. Based on the optimal plating efficacy (depending on the BA treatment and irradiation dose), 500-5,000 cells were seeded in $25 \mathrm{~cm}^{2}$ flasks. The cells were cultured in RPMI supplemented with $10 \%$ FCS in a humidified atmosphere of $3 \% \mathrm{CO}_{2}$ at $37^{\circ} \mathrm{C}$. The medium was changed after 5 days. Between 10 and 14 days after irradiation, the cells were fixed with paraformaldehyde (Sigma, Deisenhofen, Germany), and colony formation was visualized by staining with $10 \%$ Giemsa solution (Sigma, Deisenhofen, Germany). Only colonies with $>50$ cells were scored to determine the surviving fraction (SF). The cytotoxicity of BA was defined as the ratio of colonies formed after treatment with different concentrations of BA to DMSO-treated control cells. The SF was defined as the ratio of colonies formed after irradiation with $0,2,6$ or 15 Gy to the number of 
colonies formed in the unirradiated controls. The enhancement factor (EF) was defined as the ratio of the SF of BA-treated cells to DMSO-treated control cells dependent on the dose of irradiation. The data represent at least three independent experiments.

\section{Migration assays and cell cycle analysis}

Cell migration was assessed using modified Boyden chambers as previously described [27]. Cells $\left(2 \times 10^{4}\right)$ were suspended in $300 \mu \mathrm{l}$ of RPMI without FCS and were then added to the upper chamber (membrane filter with $8 \mu \mathrm{m}$ pore size), while the bottom chamber was filled with $1 \mathrm{ml}$ of RPMI supplemented with $20 \%$ FCS (as a chemoattractant). The assay was performed at $37^{\circ}$ $\mathrm{C}$ in a humidified atmosphere containing $3 \% \mathrm{CO}_{2}$ for at least $16 \mathrm{~h}$. Non-migrating cells on the upper side of the transwell inserts were removed. The cells that had migrated to the bottom side of the membrane were trypsinized and counted with CASY DT (Schärfe System $\mathrm{GmbH}$, Reutlingen, Germany). The data represent at least three independent experiments.

Furthermore, we used a wound scratch assay to determine the migration of cells after treatment with BA. Cells were grown in 6-well cell culture plates in RPMI medium containing 10\% FCS and were cultured to $100 \%$ confluence. A uniform cell-free area was created by scratching the confluent monolayer with a $200 \mu \mathrm{l}$ pipette tip. To determine the migration of glioma cells, the wound closure was observed at different time points. The wound scratch assay was performed three times in independent experiments.

Cells were analyzed for cell cycle distribution. About 5 $\times 10^{5}$ cells were harvested and washed in PBS. Subsequently, 95\% ethanol was added slowly until a final concentration of $80 \%$ was reached. The DNA content, which was indicated by the extent of staining of propidium iodide, was measured by flow cytometry in an FACSscan (Becton Dickinson, Heidelberg, Germany), using the CellFit software (Version 2.0).

\section{Western blotting}

Cells were washed, trypsinized and centrifuged. The supernatant of cells was washed with PBS and resuspended in $100 \mu \mathrm{l}$ of lysis buffer $(50 \mathrm{mM}$ Tris at $\mathrm{pH}$ 8.0, $0.3 \mathrm{M} \mathrm{NaCl}, 1 \mathrm{mM}$ EDTA, $0.5 \mathrm{mM}$ dithiothreitol, 0.1\% NP40 and protease inhibitors), followed by ultrasonic homogenization. After centrifugation at $14,000 \mathrm{~g}$ for 15 min, the supernatant was collected and the protein concentration was determined using the Bradford assay (BioRad, Munich, Germany). About $30 \mu \mathrm{g}$ of total protein from each cell lysate was separated on a $10 \%$ NuPAGE Bis-Tris (Invitrogen) gel that was placed in an X-Cell SureLock Mini-Cell (Invitrogen). The membrane was blocked with $10 \%$ non-fat milk in TBST $(50 \mathrm{mM}$
$\mathrm{NaCl}, 30 \mathrm{mM}$ Tris- $\mathrm{HCl}$ at $\mathrm{pH} 8.0$ and $0.1 \%$ Tween) for $1 \mathrm{~h}$ and incubated with rabbit anti-human survivin antibody (1:1,000 dilution, clone AF886, R\&D Systems, Wiesbaden, Germany), rabbit anti-human cleaved PARP (1:2,000, Cell Signaling, Danvers, MA, USA), mouse anti-human HIF1 $\alpha$ antibody (1:1,000, BD Transduction Laboratories, Lexington, $\mathrm{KY})$ and mouse anti- $\beta$-actin (1:5,000, Sigma, Deisenhofen, Germany) at $4^{\circ} \mathrm{C}$ overnight. After washing, the membranes were incubated with a horseradish peroxidase-labeled goat anti-rabbit or anti-mouse IgG (1:2,000, DAKO, Glostrup, Denmark) for $1 \mathrm{~h}$ at room temperature. For protein detection, membranes were incubated with ECL substrate or ECL Plus Blotting Detection System for 1 min (Amersham Pharmacia Biotech, Freiburg, Germany) and exposed to X-ray film (Biomax, Kodak, Braunschweig, Germany).

\section{Statistical analyses}

The experimental results were analyzed by paired Student's t-tests. A p-value of 0.05 was considered to be significant.

\section{Results}

\section{Effects of BA on clonogenic survival}

The effects of BA on the clonogenic survival, cell migration, cell cycle, protein expression and radiosensitivity in U251MG and U343MG glioma cell lines under normoxic and hypoxic conditions were determined. With higher concentrations (from $3-30 \mu \mathrm{M}$ ), a decline in clonogenic survival was observed, with an $\mathrm{IC}_{50}$ of 23 $\mu \mathrm{M}$ in U251MG cells and $24 \mu \mathrm{M}$ in U343MG cells under normoxic conditions after an incubation time of $24 \mathrm{~h}$ (Figure 1). In addition, longer incubation with BA led to increased cytotoxicity in both cell lines (data not shown). Additionally, incubation of BA caused an increase of subG1-cells in both cell lines. However, we did not find effects of BA on cell distribution in other cell cycle phase (data not shown). Under hypoxic conditions, BA had significantly increased cytotoxicity in both glioma cell lines (Figure 2). After a $24 \mathrm{~h}$ incubation with $10 \mu \mathrm{M}$ or $15 \mu \mathrm{M}$ BA under normoxic conditions, the clonogenic survival was reduced to $79 \%(\mathrm{p}=0.07)$ or $57 \%(\mathrm{p}=0.03)$ in U251MG cells and 87\% ( $\mathrm{p}=0.15)$ or $82 \%(\mathrm{p}=0.07)$ in U343MG cells, respectively. Under hypoxic conditions, an increased reduction in survival to $30 \%(\mathrm{p}=0.01)$ or $9 \%(\mathrm{p}=0.03)$ and $46 \%(\mathrm{p}=0.10)$ or $0.8 \%(\mathrm{p}=0.03)$, respectively, was detected (Figure 2$)$.

\section{Effects of BA on cell migration and protein expression}

The effects of BA on the migration rates of both glioma cell lines were determined with the Boyden chamber assay and the scratch assay. Decreased migration rates were detected after incubation with a higher concentration of BA in both cell lines. Compared to DMSO- 

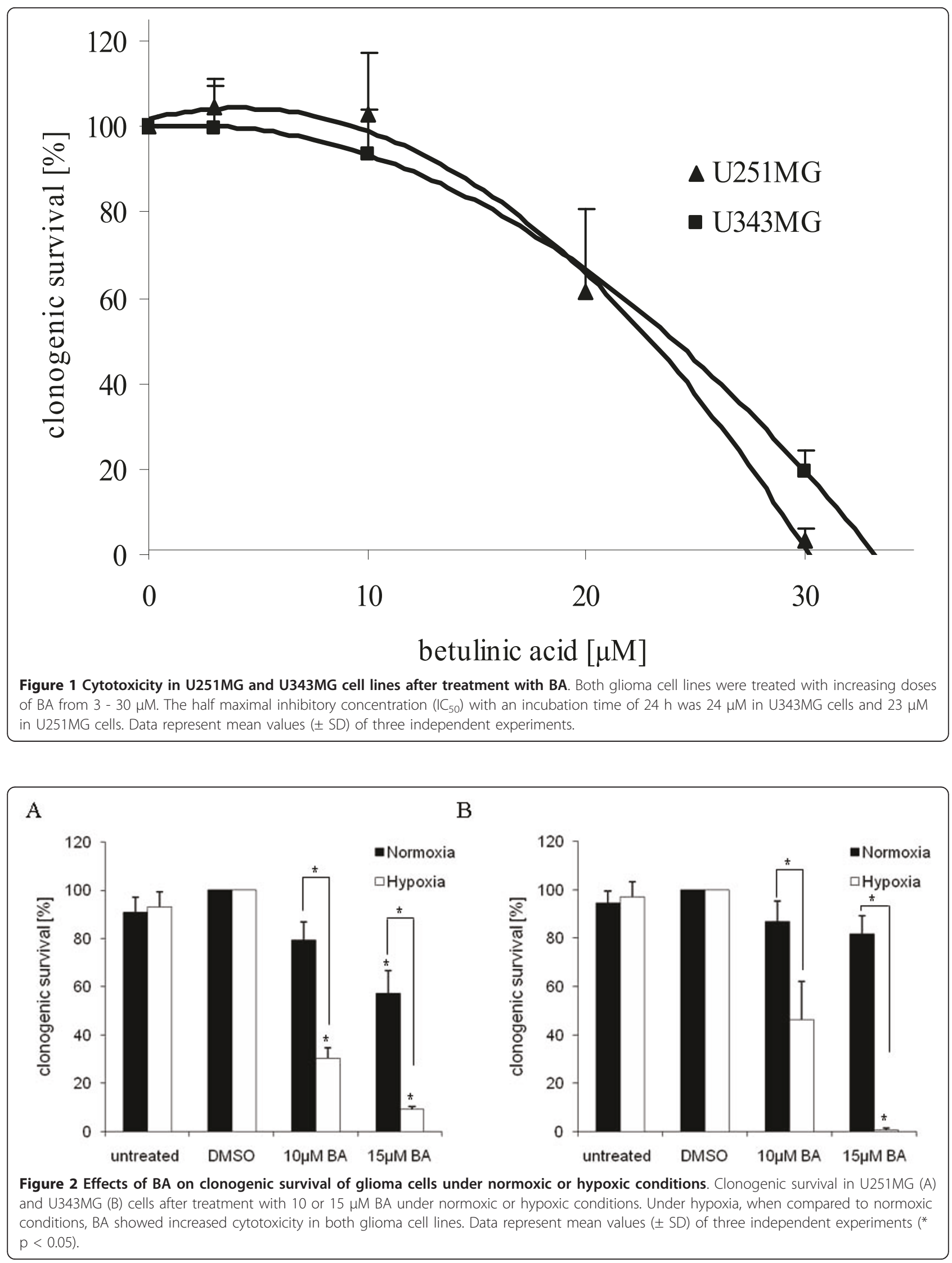


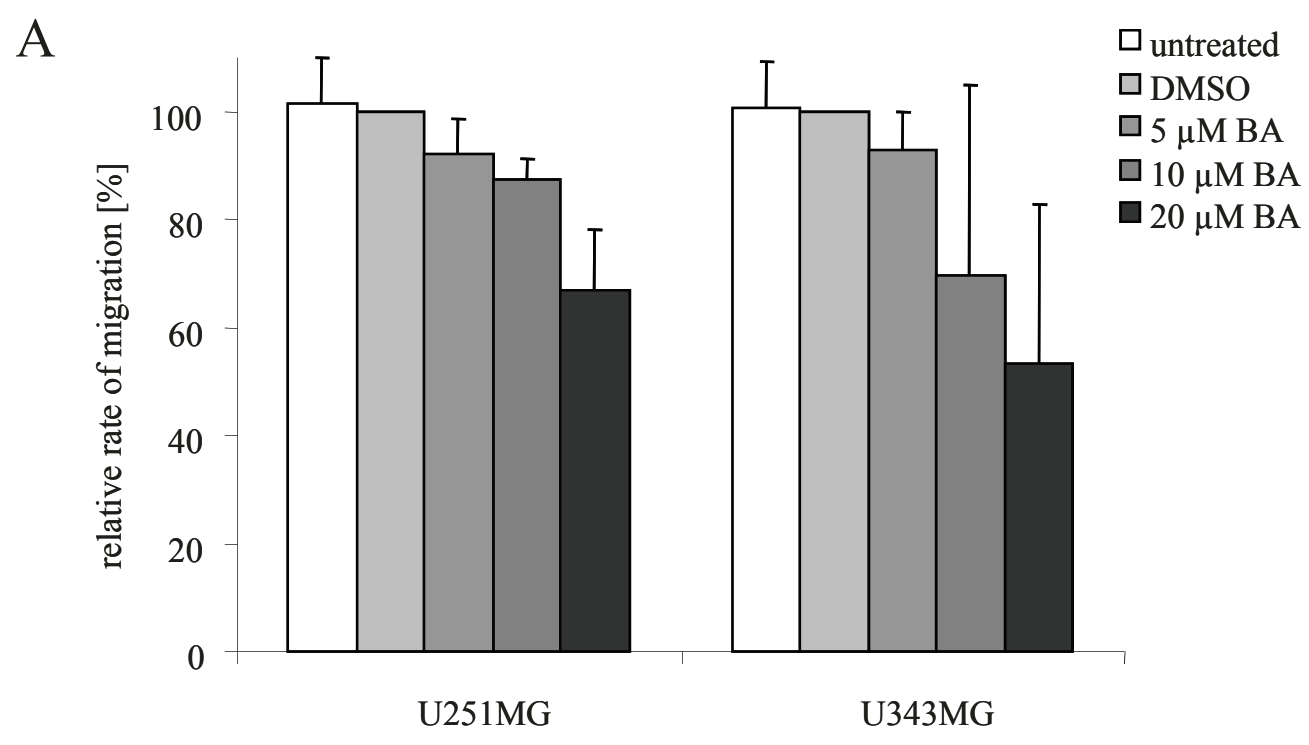

$\mathrm{B}$

DMSO

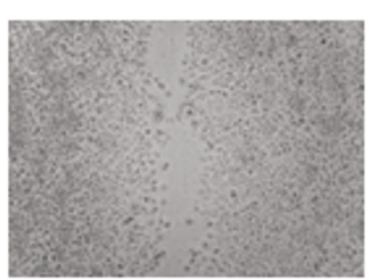

U343MG

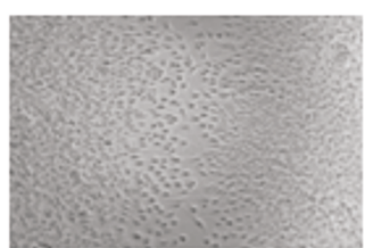

$5 \mu \mathrm{M}$ BA
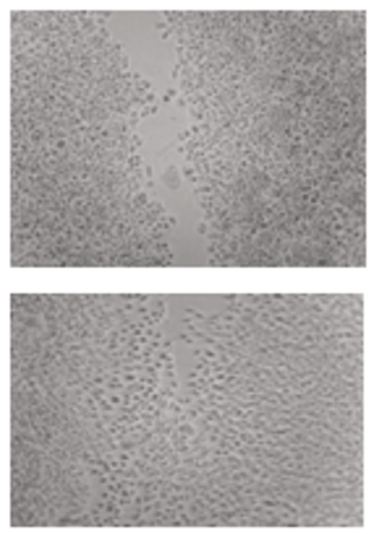

$10 \mu \mathrm{M}$ BA
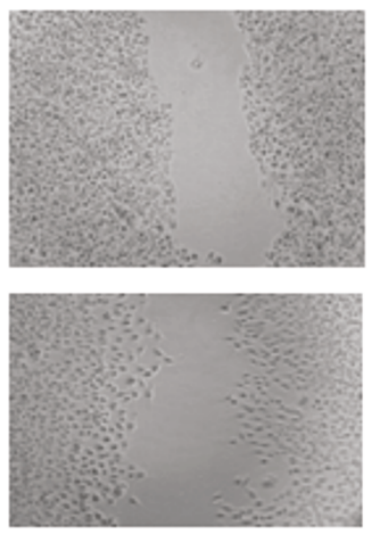

Figure 3 Effects of BA on cell migration of glioma cells. Migration rates of U251MG and U343MG cells treated with BA analyzed by Boyden chamber assays (A) and scratch assays (B) under normoxic conditions. Compared to DMSO-treated control cells, incubation with 5, 10 and 20 $\mu \mathrm{M}$ BA led to a decrease in cell migration rates in both glioma cell lines. Similarly, cells had a reduced migration rate after BA treatment as measured by the scratch assay. Data represent the average values $( \pm S D)$ of three independent experiments.

treated control cells, incubation with 5,10 and $20 \mu \mathrm{M}$ BA led to decreased cell migration rates in U251MG cells to $92 \%(\mathrm{p}=0.21), 87 \%(\mathrm{p}=0.12)$ and $67 \%(\mathrm{p}=$ 0.09 ), or in U343MG cells to $93 \%$ ( $\mathrm{p}=0.10$ ), $70 \%$ ( $\mathrm{p}=$ $0.20)$ and $53 \%(\mathrm{p}=0.08)$, respectively, under normoxic conditions (Figure 3A). Similarly, reduced migration rates were found after cells were incubated with $\mathrm{BA}$ in the scratch assay (Figure 3B).

Using Western blot analysis, we examined the cleavage of PARP (as an indicator for the induction of apoptosis) and the expression of survivin (as an inhibitor of apoptosis) (Figure 4). Incubation with 20 or $25 \mu \mathrm{M}$ BA led to PARP's cleavage, and to a decrease in survivin levels under normoxic conditions. Additionally, increased PARP's cleavage and a decrease in survivin protein levels were observed after treatment with 10 or $15 \mu \mathrm{M}$ BA in the U251MG cells under hypoxic conditions. BA also decreased hypoxia-induced levels of the HIF-1 $\alpha$ protein in both cell lines (Figure 4). However, combination of BA with radiotherapy showed no additional effects on PARP cleavage or the expression of survivin under normoxic or hypoxic conditions.

\section{Effects of BA on radiosensitivity}

Irradiation at $2 \mathrm{~Gy}$ reduced clonogenic survival to $70 \%$ $(\mathrm{SF} 2=0.70)$ in U251MG cells and 71\% $(\mathrm{SF} 2=0.71)$ in 


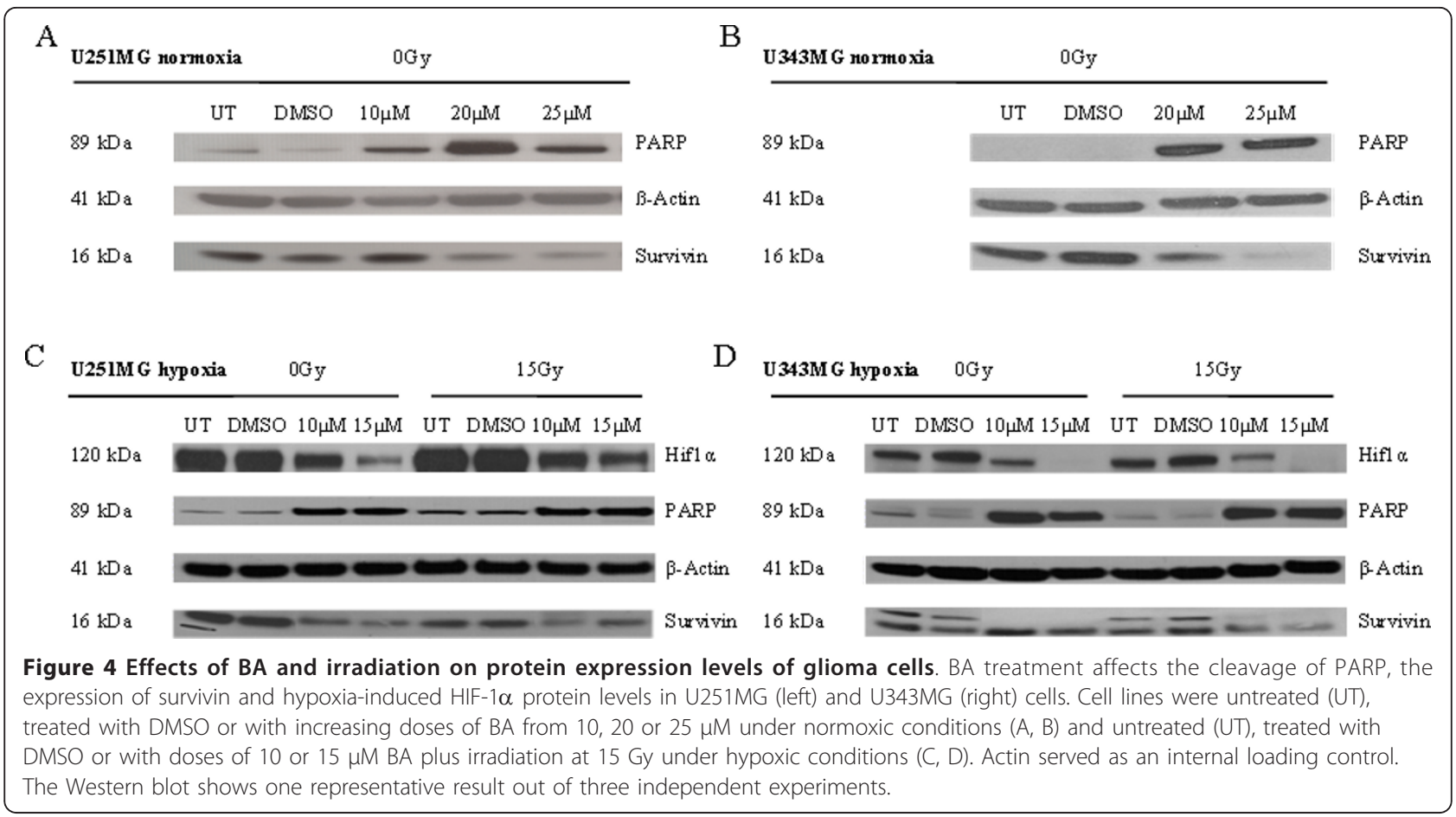

U343MG cells under normoxic conditions. Irradiationinduced clonogenic survival of U251MG and U343MG cells was increased under hypoxic conditions when compared to normoxic conditions (Figure 5). The combination of BA with radiotherapy resulted in an additive effect for U343MG cells under normoxic and hypoxic conditions. However, a weak not significant radioprotective effect was observed at $10 \mu \mathrm{M}$ BA under hypoxic conditions. In addition, a weak radiation enhancement was observed for U251MG cells under normoxic conditions. The enhancement factor at a radiation dose of 6 Gy after treatment with $20 \mu \mathrm{M}$ and $25 \mu \mathrm{M}$ BA was 1.22 $(\mathrm{p}=0.02)$ and $1.34(\mathrm{p}=0.15)$, respectively (Figure 5$)$. However, under hypoxic conditions, the effects of BA on radiosensitivity were strongly enhanced in U251MG cells. The enhancement factor at an irradiation dose of 15 Gy after $10 \mu \mathrm{M}$ or $15 \mu \mathrm{M}$ BA treatment was 2.20 (p $=0.02)$ and $4.50(\mathrm{p}=0.03)$, respectively (Figure 5).

\section{Discussion}

Betulinic acid (BA) represents a new therapeutic agent with possible uses in the treatment of glioblastoma [10]. Because of the selective cytotoxic effects of BA in tumor cells, combining BA treatment with conservative tumor therapies (such as radiotherapy and chemotherapy) is attractive. Here, we report that BA triggers cytotoxicity in human malignant glioma cells in a dose-dependent manner (Figure 1). In addition, the cytotoxic effects of BA were increased in both cell lines under hypoxic conditions (Figure 2). In accordance with our investigations,
BA was found to be a highly potent cell-death promoting agent in primary glioblastoma cells and cell lines $[10,28]$. However, $17 \%$ (4 of 24) primary glioblastoma cells did not respond to treatment with BA [10]. An activated EGFR/AKT pathway and the expression of survivin contributed to a lower sensitivity in response to BA treatment in human melanoma cells [29].

In the present study, the increased cytotoxicity in both glioma cell lines was dependent on BA concentration. Additionally, it was coupled with an inhibition of cell migration, the cleavage of the apoptotic protein PARP and a decrease in the protein level of the apoptosis inhibitor survivin (Figure 3 and 4). In agreement with our current findings, BA was also found to inhibit the migration of glioma (C6), lung carcinoma (A549) and medulloblastoma (TE671) cells [15]. In addition, BA-induced inhibition of migration was associated with the suppression of mRNA and protein levels of MMP-2 and MMP-9 in vascular smooth muscle cells [30]. It is well known that the activation of these two matrix metalloproteinases is involved in cellular invasion and migration. Recent studies also detected BA as an inhibitor of migration, invasion and angiogenesis $[14,16]$. Furthermore, different analyses have shown that BA induces apoptosis in tumor cell lines $[8,11,12,31]$. BA-induced apoptosis can be associated with cytochrome c release, the activation of caspases, the cleavage of PARP and modulation of $\mathrm{Bcl} 2$ family protein levels in glioma cells $[10,17,32]$. However, overexpression of the anti-apoptotic protein $\mathrm{Bcl}-2$ only partially delayed the induction of apoptosis in Jurkat cells 


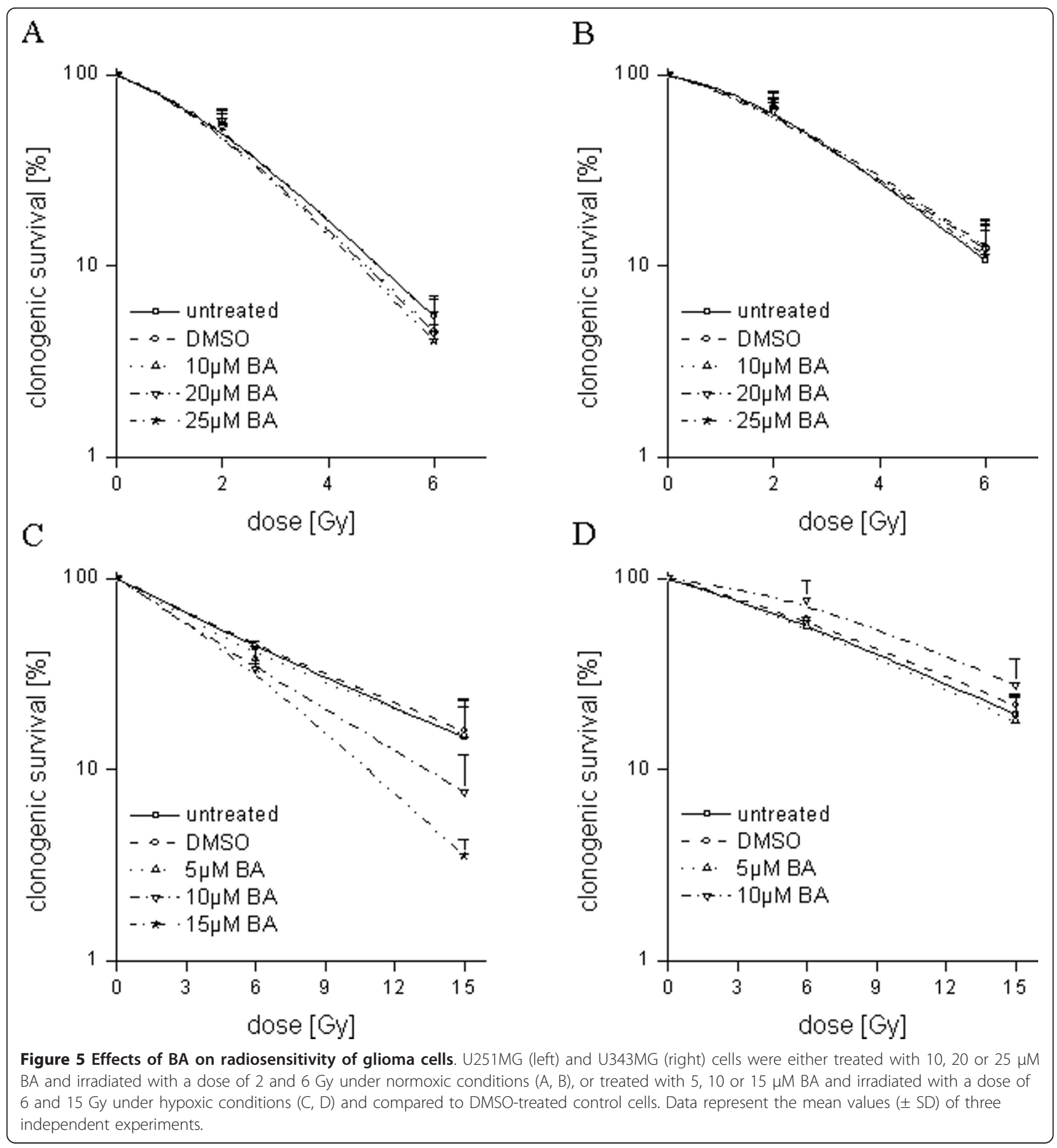

[13]. Somewhat controversial is the finding that in head and neck cancer cells, BA-induced cytotoxic effects were linked to a decreased level of Bax, an inducer of apoptosis [33]. In prostate cancer cells, the combination of docetaxel and BA increased NF- $\kappa \mathrm{B}$ activity and stimulated apoptosis [34]. Altogether, the exact mechanisms by which BA might act as an effective and wide-range anticancer agent remain unclear.
First investigations studying the effect of BA treatment in combination with other chemotherapeutic drugs showed that BA improved the cytotoxic effects of different agents. In the mouse melanoma cell line B16F10, BA improved vincristine-induced cytotoxic effects in vitro, in addition to reducing the number of metastases in vivo [7]. Sublines of the colon cancer cell line SNUC5 that are resistant to chemotherapy showed 
significantly increased cytotoxicity when 5-fluorouracil, irinotecan or oxaliplatin were combined with BA treatment [23]. In addition, BA augmented doxorubicin- or cisplatin-induced apoptosis in several different tumor cell lines, while no apoptosis was induced by BA treatment in untransformed fibroblasts [31]. However, the addition of BA in SCC9 and SCC25 head and neck tumor cell lines had no effects on cisplatin-induced apoptosis [35]. In recent studies, glioma cell lines were characterized as radioresistant, with a low rate of irradiation-induced apoptosis [36-38]. Our analyses show that $\mathrm{BA}$, in combination with radiotherapy, resulted in an additive effect for the U343MG cells and a weak radiation enhancement for U251MG cells under normoxic conditions (Figure 5). This is in agreement with two studies that dealt with testing a combination of BA treatment and radiotherapy for its effects on two melanoma [24] and two head and neck cancer cell lines [25]. These studies showed that these two treatments were more effective in combination. The present data also demonstrate that BA strongly enhances the radiosensitivity of U251MG cells under hypoxic conditions (Figure 5). To our knowledge, this is the first study demonstrating that BA can increase cytotoxicity and radiosensitivity under hypoxic conditions. These effects are coupled with the inhibition of the hypoxia-induced increase of HIF-1 $\alpha$ protein level (Figure 4). In accordance with results presented here, a decrease of HIF-1 $\alpha$ after BA treatment has been described in adenocarcinoma cells [39]. Recently, our group showed that the silencing of HIF- $1 \alpha$ by siRNA or chetomin resulted in a significantly enhanced cytotoxicity and radiosensitivity in both human glioma cell lines [38], in addition to HT1080 human fibrosarcoma cells $[40,41]$. The downregulation of HIF- $1 \alpha$ consistently increased the sensitivity of human glioma cells to doxorubicin and etoposide [42].

\section{Conclusions}

In summary, BA affects the clonogenic survival, migration and apoptosis in human malignant glioma cells. Remarkably, additional effects on cytotoxicity and radiation sensitivity were observed under hypoxic conditions. These results suggest that BA may be suitable for improving the treatment of malignant gliomas. However, more investigations are necessary to characterize its role as chemotherapeutic drug and potential radiosensitizer.

\section{List of abbreviations}

BA: betulinic acid, IC $C_{50}$ : half maximal inhibitory concentration, SF: survival fraction, EF: Enhancement factor, UT: untreated, DMSO: dimethyl sulfoxide

\section{Acknowledgements}

We would like to thank our colleagues from the Department of Radiotherapy for contributing to this study and for their continuous support. We would also like to thank Gabriele Thomas and Kathrin Spröte for their excellent technical assistance. Betulinic acid was obtained as a kind gift from BioSolutions Halle GmbH (Halle, Germany). This work was supported by the Wilhelm Roux program of BMBF/NBL3 (grant number: FKZ: 21/30).

\section{Author details}

${ }^{1}$ Department of Radiotherapy, Martin-Luther-University Halle-Wittenberg, Dryanderstr. 4, 06110 Halle, Germany. ${ }^{2}$ Department of Oral and Maxillofacial Plastic Surgery, Martin-Luther-University Halle-Wittenberg, Ernst-Grube-Str. 40, 06120 Halle, Germany. ${ }^{3}$ Biozentrum, Martin-Luther-Universität HalleWittenberg, Weinbergweg 22, 06120 Halle, Germany. ${ }^{4}$ Div. Molecular Urology, Clinic of Urology, University Hospital Erlangen, Erlangen, Germany and Nikolaus-Fiebiger-Center for Molecular Medicine, Friedrich Alexander University Erlangen-Nürnberg, Germany.

\section{Authors' contributions}

MB and DV designed the study, analyzed the data and drafted the manuscript.

MPZ, SP performed experimental procedures, analyzed the data and drafted the manuscript.

JK, HW, MK, RP, GNK, HK and HT aided in study design, analyzed the data and reviewed the manuscript. All authors read and approved the final manuscript.

\section{Competing interests}

The authors declare that they have no competing interests.

Received: 25 May 2011 Accepted: 9 September 2011

Published: 9 September 2011

\section{References}

1. Sheline GE: Radiation therapy of brain tumors. Cancer 1977, 39:873-881.

2. Eiznhamer DA, Xu ZQ: Betulinic acid: a promising anticancer candidate. IDrugs 2004, 7:(4): 359-373.

3. Alakurtti S, Mäkelä T, Koskimies S, Yli-Kauhaluoma J: Pharmacological properties of the ubiquitous natural product betulin. Eur J Pharm Sci 2006, 29(1):1-13

4. Kessler JH, Mullauer FB, de Roo GM, Medema JP: Broad in vitro efficacy of plant-derived betulinic acid against cell lines derived from the most prevalent human cancer types. Cancer Lett 2007, 251(1):132-145.

5. Pisha $\mathrm{E}$, Chai $H$, Lee IS, Chagwedera TE, arnsworth NR, Cordell GA,

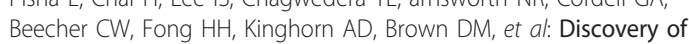
betulinic acid as a selective inhibitor of human melanoma that functions by induction of apoptosis. Nat Med 1995, 1(10):1046-1051.

6. Zuco V, Supino R, Righetti SC, Cleris L, Marchesi E, Gambacorti-Passerini C, Formelli F: Selective cytotoxicity of betulinic acid on tumor cell lines, but not on normal cells. Cancer Lett 2002, 175(1):17-25.

7. Sawada N, Kataoka K, Kondo K, Arimochi H, Fujino H, Takahashi Y, Miyoshi T, Kuwahara T, Monden Y, Ohnishi Y: Betulinic acid augments the inhibitory effects of vincristine on growth and lung metastasis of B16F10 melanoma cells in mice. Br J Cancer 2004, 90(8):1672-1678.

8. Fulda S, Friesen C, Los M, Scaffidi C, Mier W, Benedict M, Nuñez G, Krammer PH, Peter ME, Debatin KM: Betulinic acid triggers CD95 (APO-1/ Fas)- and p53-independent apoptosis via activation of caspases in neuroectodermal tumors. Cancer Res 1997, 57(21):4956-4964.

9. Sandberg F, Dutschewska H, Christov V, Spassov S: Spondianthus preussii var. glaber Engler: Pharmacological screening and occurrence of triterpenes. Acta Pharm Suec 1987, 24:253-256.

10. Fulda S, Jeremias I, Steiner HH, Pietsch T, Debatin KM: Betulinic acid: a new cytotoxic agent against malignant brain-tumor cells. Int J Cancer 1999, 82(3):435-441.

11. Kasperczyk H, La Ferla-Brühl K, Westhoff MA, Behrend L, Zwacka RM, Debatin KM, Fulda S: Betulinic acid as new activator of NF-kappaB: molecular mechanisms and implications for cancer therapy. Oncogene 2005, 24(46):6945-6956.

12. Rabi T, Shukla S, Gupta S: Betulinic acid suppresses constitutive and TNFalpha-induced NF-kappaB activation and induces apoptosis in human prostate carcinoma PC-3 cells. Mol Carcinog 2008, 47(12):964-973.

13. Mullauer FB, Kessler JH, Medema JP: Betulinic acid induces cytochrome c release and apoptosis in a Bax/Bak-independent, permeability transition pore dependent fashion. Apoptosis 2009, 14(2):191-202. 
14. Kwon HJ, Shim JS, Kim JH, Cho HY, Yum YN, Kim SH, Yu J: Betulinic acid inhibits growth factor-induced in vitro angiogenesis via the modulation of mitochondrial function in endothelial cells. Jpn J Cancer Res 2002, 93(4):417-425.

15. Rzeski W, Stepulak A, Szymański M, Sifringer M, Kaczor J, Wejksza K, Zdzisińska B, Kandefer-Szerszeń M: Betulinic acid decreases expression of bcl-2 and cyclin D1, inhibits proliferation, migration and induces apoptosis in cancer cells. Naunyn Schmiedebergs Arch Pharmacol 2006, 374(1):11-20.

16. Chintharlapalli S, Papineni S, Ramaiah SK, Safe S: Betulinic acid inhibits prostate cancer growth through inhibition of specificity protein transcription factors. Cancer Res 2007, 67(6):2816-2823.

17. Wick W, Grimmel C, Wagenknecht B, Dichgans J, Weller M: Betulinic acidinduced apoptosis in glioma cells: A sequential requirement for new protein synthesis, formation of reactive oxygen species, and caspase processing. J Pharmacol Exp Ther 1999, 289(3):1306-1312.

18. Tan Y, Yu R, Pezzuto JM: Betulinic acid-induced programmed cell death in human melanoma cells involves mitogen-activated protein kinase activation. Clin Cancer Res 2003, 9(7):2866-2875.

19. Ganguly A, Das B, Roy A, Sen N, Dasgupta SB, Mukhopadhayay S, Majumder HK: Betulinic acid, a catalytic inhibitor of topoisomerase I, inhibits reactive oxygen species-mediated apoptotic topoisomerase IDNA cleavable complex formation in prostate cancer cells but does not affect the process of cell death. Cancer Res 2007, 67(24):11848-11858.

20. Collingridge DR, Piepmeier JM, Rockwell S, Knisely JP: Polarographic measurements of oxygen tension in human glioma and surrounding peritumoral brain tissue. Radiother Oncol 1999, 53(2):127-131.

21. Jensen RL: Hypoxia in the tumorigenesis of gliomas and as a potential target for therapeutic measures. Neurosurg Focus 2006, 20(4):E24.

22. Flynn JR, Wang L, Gillespie DL, Stoddard GJ, Reid JK, Owens J, Ellsworth GB, Salzman KL, Kinney AY, Jensen RL: Hypoxia-regulated protein expression, patient characteristics, and preoperative imaging as predictors of survival in adults with glioblastoma multiforme. Cancer 2008, 113(5):1032-1042.

23. Jung GR, Kim KJ, Choi CH, Lee TB, Han SI, Han HK, Lim SC: Effect of betulinic acid on anticancer drug-resistant colon cancer cells. Basic Clin Pharmacol Toxicol 2007, 101(4):277-285.

24. Selzer E, Pimentel E, Wacheck V, Schlegel W, Pehamberger $H$, Jansen B, Kodym R: Effects of betulinic acid alone and in combination with irradiation in human melanoma cells. J Invest Dermatol 2000, 114(5):935-940.

25. Eder-Czembirek C, Erovic BM, Czembirek C, Brunner M, Selzer E, Pötter R, Thurnher D: Betulinic Acid a Radiosensitizer in Head and Neck Squamous Cell Carcinoma Cell Lines. Strahlenther Onkol 2010, 186:143-148.

26. Kappler M, Rot S, Taubert H, Greither T, Bartel F, Dellas K, Hänsgen G, Trott KR, Bache M: The effects of knockdown of wild-type survivin, survivin-2B or survivin-delta3 on the radiosensitization in a soft tissue sarcoma cells in vitro under different oxygen conditions. Cancer Gene Ther 2007, 14(12):994-1001.

27. Hahnel A, Wichmann H, Kappler M, Kotzsch M, Vordermark D, Taubert H, Bache M: Effects of osteopontin inhibition on radiosensitivity of MDAMB-231 breast cancer cells. Radiat Oncol 2010, 5:82.

28. Jeremias I, Steiner HH, Benner A, Debatin KM, Herold-Mende C: Cell death induction by betulinic acid, ceramide and TRAIL in primary glioblastoma multiforme cells. Acta Neurochir 2004, 146(7):721-729.

29. Qiu L, Wang Q, Di W, Jiang Q, Schefeller E, Derby S, Wanebo H, Yan B, Wan Y: Transient activation of EGFR/AKT cell survival pathway and expression of survivin contribute to reduced sensitivity of human melanoma cells to betulinic acid. Int J Oncol 2005, 27(3):823-830.

30. Yoon JJ, Lee YJ, Kim JS, Kang DG, Lee HS: Betulinic acid inhibits high glucose-induced vascular smooth muscle cells proliferation and migration. J Cell Biochem 2010, 111(6):1501-1511.

31. Fulda S, Debatin KM: Sensitization for anticancer drug-induced apoptosis by betulinic Acid. Neoplasia 2005, 7(2):162-170.

32. Li Y, He K, Huang Y, Zheng D, Gao C, Cui L, Jin YH: Betulin induces mitochondrial cytochrome $\mathrm{c}$ release associated apoptosis in human cancer cells. Mol Carcinog 2010, 49(7):630-640.

33. Thurnher D, Turhani D, Pelzmann M, Wannemacher B, Knerer B Formanek $M$, Wacheck $V$, Selzer E: Betulinic acid: a new cytotoxic compound against malignant head and neck cancer cells. Head Neck 2003, 25(9):732-740.
34. Parrondo R, de las Pozas A, Reiner T, Rai P, Perez-Stable C: NF-kappaB activation enhances cell death by antimitotic drugs in human prostate cancer cells. Mol Cancer 2010, 9:182.

35. Eder-Czembirek C, Czembirek C, Erovic BM, Selzer E, Turhani D, Vormittag L, Thurnher D: Combination of betulinic acid with cisplatin-different cytotoxic effects in two head and neck cancer cell lines. Oncol Rep 2005, 14(3):667-671.

36. Shu HK, Kim MM, Chen P, Furman F, Julin CM, Israel MA: The intrinsic radioresistance of glioblastoma-derived cell lines is associated with a failure of p53 to induce p21(BAX) expression. Proc Natl Acad Sci USA 1998, 95:14453-14458.

37. Bassi C, Mello SS, Cardoso RS, Godoy PD, Fachin AL, Junta CM, SandrinGarcia P, Carlotti CG, Falcão RP, Donadi EA, Passos GA, Sakamoto-Hojo ET: Transcriptional changes in U343 MG-a glioblastoma cell line exposed to ionizing radiation. Hum Exp Toxicol 2008, 27(12):919-929.

38. Kessler J, Hahnel A, Wichmann H, Rot S, Kappler M, Bache M, Vordermark D: HIF-1a inhibition by siRNA or chetomin in human malignant glioma cells: effects on hypoxic radioresistance and monitoring via CA9 expression. BMC Cancer 2010, 10:605.

39. Karna E, Szoka L, Palka JA: Betulinic acid inhibits the expression of hypoxia-inducible factor 1 alpha and vascular endothelial growth factor in human endometrial adenocarcinoma cells. Mol Cell Biochem 2010, 340: (1-2):15-20.

40. Staab A, Loeffler J, Said HM, Diehlmann D, Katzer A, Beyer M, Fleischer M, Schwab F, Baier K, Einsele H, Flentje M, Vordermark D: Effects of HIF-1 inhibition by chetomin on hypoxia-related transcription and radiosensitivity in HT 1080 human fibrosarcoma cells. BMC Cancer 2007, 7:213.

41. Staab A, Fleischer M, Loeffler J, Said HM, Katzer A, Plathow C, Einsele H, Flentje $M$, Vordermark D: Small interfering RNA targeting HIF-1a reduces hypoxia-dependent transcription and radiosensitizes hypoxic HT 1080 human fibrosarcoma cells in vitro. Strahlenther Onkol 2011, 187(4):252-259.

42. Chen L, Feng P, Li S, Long D, Cheng J, Lu Y, Zhou D: Effect of hypoxiainducible factor-1alpha silencing on the sensitivity of human brain glioma cells to doxorubicin and etoposide. Neurochem Res 2009, 34(5):984-990.

doi:10.1186/1748-717X-6-111

Cite this article as: Bache et al:: Increased betulinic acid induced cytotoxicity and radiosensitivity in glioma cells under hypoxic conditions. Radiation Oncology 2011 6:111.

\section{Submit your next manuscript to BioMed Central and take full advantage of:}

- Convenient online submission

- Thorough peer review

- No space constraints or color figure charges

- Immediate publication on acceptance

- Inclusion in PubMed, CAS, Scopus and Google Scholar

- Research which is freely available for redistribution

Submit your manuscript at www.biomedcentral.com/submit
C Biomed Central 